\title{
An Exploratory Study on Using Wiki to Foster Student Teachers' Learner-centered Learning and Self and Peer Assessment
}

\author{
Eugenia M. W. Ng and Yiu Chi Lai \\ The Hong Kong Institute of Education, Hong Kong SAR, China
}

\author{
eugenia@ied.edu.hk yiuchi@ied.edu.hk
}

Executive Summary

This article discusses an exploratory study that examined whether a wiki-based project could foster student-centered learning. Student teachers were divided into five groups to tackle a group project which involved creating digital learning materials on wiki that could teach information technology (IT) to secondary school students. As assessment is a part of learning, they were also required to develop an assessment rubric to assess the wiki pages created by themselves and their peers. It was observed that a variety of learning resources, such as videos, newspaper clippings, and cartoons, were included in the groups' wiki pages. The student teachers also came up with assessment rubrics for self and peer assessment of their wiki pages by adopting or adapting assessment rubrics available on the Internet. However, the assessment rubrics did not seem to provide clear assessment guidelines as there were large differences among the groups in terms of assessing the wiki pages. In sum, it appears that wiki can facilitate student-centered activities as the statistics logs gathered from the wiki site indicated that the student teachers often revised their wiki project materials, especially after receiving feedback from their peers and course instructors.

Keywords: assessment rubrics, learner-centered learning, self assessment, peer assessment, student teacher

\section{Introduction}

Many people assume that student teachers, digital natives (Prensky, 2005) who have grown up with technology, automatically know how to integrate technology into their teaching, and yet the reverse has been found (Lei, 2009; Pope, Hare, \& Howard, 2002; Russell, Bebell, O’Dwyer, \& O'Connor, 2003). Student teachers are very competent in using information technology (IT) in their daily lives, and yet they may not have a clear idea of how to integrate IT into teaching and learning. Therefore, it is important for teacher education programs to integrate content, pedagogy, and technology (Hughes, 2005; Koehler, Mishra, \& Yahya, 2007) and also for teacher educators to model IT pedagogical competencies in classroom teaching (Gomez, Sherin, \& Griesdorn,

Material published as part of this publication, either on-line or in print, is copyrighted by the Informing Science Institute. Permission to make digital or paper copy of part or all of these works for personal or classroom use is granted without fee provided that the copies are not made or distributed for profit or commercial advantage AND that copies 1) bear this notice in full and 2) give the full citation on the first page. It is permissible to abstract these works so long as credit is given. To copy in all other cases or to republish or to post on a server or to redistribute to lists requires specific permission and payment of a fee. Contact Publisher@InformingScience.org to request redistribution permission.
2008; Kim \& Hannafin, 2009; Lim \&

Chan, 2007; Nicholas \& Ng, 2009).

\section{Characteristics of Web 2.0}

The term "Web 2.0" was coined by O'Reilly in 2004. Users of Web 2.0 not only create and own data but also mix, amend, and recombine content, and they are relatively more "open to the world," welcoming comments and revisions 
Using Wiki to Foster Student Teachers' Learner-centered Learning and Self and Peer Assessment

(McLoughlin \& Lee, 2007). Barlow (2008) argues that Web 2.0 tools also offer an exciting opportunity to create a classroom without walls as they provide a huge and untapped resource for educators. A popular Web 2.0 environment, wikis, enables users to publish their products on the Internet easily (Heafner \& Friedman, 2008). The editing and history features of wikis are particularly helpful for users to trace the content and timing of revisions. Indeed, there are a number of studies which have found that wikis can foster collaborative learning, particularly in the area of primary to university level written English (Mak \& Coniam, 2008; Wang, 2010). Lai and Ng (2011) also argue that wiki-based activities are effective for developing student teachers' generic skills. Generic skills include collaborative skills, communication skills, creativity, critical thinking skills, skills in using IT, numeric skills, problem-solving skills, self-management skills, and study skills (Education Commission, 2000). Wikis are also useful for fostering a deep understanding of social studies (Heafner \& Friedman, 2008) and helping pre-service teachers to produce high quality science materials (Nicholas \& Ng, 2009). Nevertheless, some drawbacks have been reported. For example, Wheeler, Yeomans, and Wheeler (2008) reported that students were frustrated by the complex structure of wikis and inhibited by the openness and the high level of participation involved in wiki work.

\section{Using IT to Foster Learning}

The traditional way of learning, with its emphasis on memorization, especially of content knowledge but also of facts and procedures, can no longer cope with the ever changing world. The new way of learning embraces interaction with the world (Biggs, 2001). Besides interaction, it is also important to acknowledge learners' prior knowledge and to help learners acquire and construct new knowledge (Vygotsky, 1978). Therefore, the learner-centered learning approach is one of the approaches used to cater for individual learning needs. Using IT as the medium can foster learnercentered learning as it allows learners to learn at their own pace and in their own time through interaction with digital materials or through interaction among people (Lee \& Woods, 2010; Wong, Kamarish, \& Tang, 2006). There are various forms of digital materials, such as simulations, educational games (Jonassen, Peck, \& Wilson, 1999; Laurillard, 2002), web-based video clips, and digital stories (Hur, 2009). Compared with printed materials, multimedia materials are more simulating and engaging (Jonassen et al., 1999). Jonassen (2000) further argues that IT can be used as a mind tool for enhancing critical and higher order learning. On the other hand, Web 2.0 authoring is thought to engage students, foster peer learning and creative expression, and develop communication skills and information literacy (Barnes \& Tynan, 2007; Berlanga et al., 2007; J. Brown \& Adler, 2008; Godwin, 2007; Lamb \& McLaughlin, 2008; Renner, 2006).

\section{Assessment}

Morris (1995) suggests that there are six major reasons for carrying out an assessment - grading, selection, mastery, guidance, prediction, and diagnosis - and that assessment should be one of the basic components of a curriculum. However, assessment should be embedded in the learning process in order to provide formative feedback to learners to improve their learning; that is to say, it should be assessment for learning rather than assessment at the end of learning activities to evaluate or select learners. Similarly, according the principle of constructive alignment, there is a need for an alignment between intended learning outcomes, student learning activities, and assessment tasks (Biggs, 2003).

Peer assessment is a formative and student-centered evaluation method which has been described as a natural process for making critical judgments of peers (Fry, 1990). Peer assessment is considered educationally sound as it values students' sense of ownership and control over their work (Oldfield \& MacAlpine, 1995; Orsmond, Merry, \& Reiling, 2000). It is particularly relevant to today's workplace where teamwork is emphasized and the ability to assess the performance of 
oneself and one's peers is essential (S. Brown \& Knight, 1994). Furthermore, well-constructed self-assessment and peer-assessment exercises have the potential to provide valuable learning experiences and encourage lifelong learning (Berry, 2008). IT undoubtedly can assist by providing a tool or medium for students to collaborate, discuss, provide feedback, and reflect on their own group work. It is the responsibility of teacher-educators to foster learners as designers and evaluators whose student-centered learning and critical thinking skills can be transferred to the real-world setting outside the classroom. However, the versatility of Web 2.0 authoring work may also pose significant challenges to assessment and hinder its further adoption (Anderson, 2007; Dron, 2006; Elliott, 2007; Nillson, Eklof, \& Ottosson, 2005; Roberts, 2007; Sankey \& Huijser, 2009; Selwyn, 2007; The New Media Consortium \& EDUCASE Learning Initiative, 2008). On the other hand, assessment rubrics when given to students prior to an assessment might guide them to perform to the level that they wish to achieve (Huba \& Freed, 2000; Palloff \& Pratt, 2003).

In light of the principle of constructive alignment, a wiki-based project was designed to align with the intended learning outcomes, student learning activities, and assessment tasks (Biggs, 2003) of student teachers who intend to teach IT in secondary schools. Wiki was chosen as the IT platform to support such an exploratory study because it is user friendly, involves no extra costs, and, most importantly, can support various forms of collaborative learning tasks. This article examines whether wiki can foster student-centered activities and whether an assessment rubric can serve as a viable tool for assessing wiki-based activities since such assessment is substantially different from assessing other IT-based activities due to the interactivity and cooperative effort involved in such activities (Gray, Thompson, Sheard, Clerehan, \& Hamilton, 2010). The following section discusses the research setting and findings. Finally, conclusions are drawn and future research directions discussed.

\section{The Research Methodology}

The study was conducted at the Hong Kong Institute of Education (HKIEd), the major teacher education provider in Hong Kong. The study's participants were student teachers enrolled in three different programs who were preparing, upon graduation, to teach IT or related subjects to pupils in secondary schools. All of them had taken a course in assessment and two courses in the IT curriculum and teaching methods.

\section{The Participants}

There were 16 participants in this study. One group of participants consisted of four students who were taking a one-year full-time Postgraduate Diploma in Education (Secondary) program (hereafter termed the FT PGDE) and another group consisted of three students who were studying a two-year part-time Postgraduate Diploma in Education (Secondary) program (hereafter termed the PT PGDE). The other three groups of participants were enrolled in a four-year full-time Bachelor of Science in Mathematics and Information Technology Education program (hereafter termed the MAIE) and were in their final year of study, which is equivalent to the PDGE level. Each group of MAIE students consisted of three students. All of the PGDE students were male and each group of MAIE students consisted of at least one female and one male student.

The MAIE students were studying both mathematics and IT at the Hong Kong University of Science and Technology, but they were also taking education and teaching methods courses at HKIEd. The majority of the MAIE students were secondary school graduates, while most FT PGDE students were recent college graduates, although some of them had one or two years work experience. On the other hand, the PT PGDE students were either IT teachers or IT technicians in secondary schools. The FT and PT PGDE students attended classes together due to the small number of students enrolled in each of these programs. 
Using Wiki to Foster Student Teachers' Learner-centered Learning and Self and Peer Assessment

\section{The Tasks}

An engaging learning design needs to take learners' prior knowledge and their desire to learn into consideration and should also acknowledge the learning context. During the period of this study, the MAIE students were taking a "Supporting Information Technology in Schools" course while the PGDE students were taking a "Learning and Teaching of Selected Topics in Information Technology" course. To integrate content, pedagogy, and technology (Hughes, 2005; Koehler et al., 2007), the course tutors created a wiki site (Project link:

http://sites.google.com/site/teachandlearnict ) which was provided free of charge by Google Sites. Each group was required to select a topic related to the "social implications of IT," namely internet addiction, internet privacy, browsers and security, privacy threats on the Internet, and ordinances against computer crime and unauthorized access. "Social implications" makes up one of the five major content areas of the new secondary school ICT curriculum in Hong Kong. They were also required to develop an assessment rubric for themselves and others to evaluate their projects. They were given a brief demonstration on how to use the editing functions to create materials on wiki. In keeping with Hong Kong's official language policy of "biliteracy and trilingualism," the students could post the materials in either Chinese or English.

The wiki project guidelines were uploaded on to the wiki site for easy reference. Students were required to perform five main tasks: (1) to create learning materials in the designated wiki site for pupils at secondary school level to learn the selected topic (Lee \& Woods, 2010; Wong et al., 2006); (2) to provide constructive comments to their peers to improve the content of the learning materials (Berry, 2008; Morris, 1995); (3) to develop and design an assessment rubric that could be used to assess their wiki sites; (4) to use their own assessment rubric to assess their own wiki site and the wiki sites of the others (for example, Group A students used the rubric they designed to assess the wiki sites of all of the other groups); and (5) to write a reflection on this project.

\section{The Research Objectives}

Prior researchers have argued that online activities should be authentic and useful (Basque, Dao, \& Contamines, 2005; Paige, Lloyda, \& Chartres, 2008) and contain enough elements for every team member to work on (Nicholas \& Ng, 2009). The wiki task in this study should have helped the participants to achieve the objectives of both courses (MAIE and PGDE) as it essentially helped to "develop participants' ability to coordinate and manage issues related to ICT management in school" (MAIE course) and also to "enhance participants' ability to select appropriate strategies to create learning environments for their students that foster the learning and teaching of ICT subjects" (PGDE course).

The wiki-based project in this study was designed not only to enable the participants to attain their course learning objectives but also to enable the researchers to explore whether wiki can support student-centered learning and assessment activities. To attain the research objective, the following research questions were posed:

1. Can wiki provide a platform for promoting student-centered learning?

2. How do student teachers come up with assessment rubrics for assessing wiki-based projects?

3. What essential elements are included in their assessment rubrics?

4. Can assessment rubrics serve as viable guidelines for evaluating wiki projects? 


\section{Findings from Wiki Sites}

To improve the validity of the results and to minimize the subjectivity of the researchers' interpretation, data were collected from multiple sources: the contents of the wiki group pages that were created and the access logs gathered by the wiki site (Yin, 2009). The results of using assessment rubrics for self-assessment and peer-assessment activities were compared and analyzed to answer the research questions.

\section{Research Question 1}

Similar to some findings (Nicholas \& Ng, 2009), the contents of the learning materials created on the wiki site demonstrated that the students had created high quality learning materials for pupils to learn social implication topics (Figure 1). Apart from text, a variety of learning resources such as video, newspaper clippings, and cartoons were also embedded in the groups' wiki site (Figure 2). All of the resources were hyperlinked to selected Internet resources. This referencing practice not only enables pupils to access to details conveniently but also provides the sources of the contents. The contents of each group's work will be discussed in detail below.

\section{Privacy Threas on the Internet}

\section{Leaching Objective:}

Student should able to describe and distinct different kinds of Privacy Threats on the Internet, and the methods to avoid affected by those Threats.

\section{Hacking(駭客入侵)}

\section{Spam(垃圾郵件)}

\section{Phishing(釣魚)}

\section{Ways to Maintain Privacy}

\section{$\underline{\text { 5. Assessment rubric }}$}

6. Other news reference

\section{Reflection}

Figure 1: An example of a Table of Contents 
Using Wiki to Foster Student Teachers' Learner-centered Learning and Self and Peer Assessment

\section{Learning Task1:}

a.

Ask the students to find some Phishing web of local bank in the internet,

They may find it how difficult to distinguish the real and the fake one.

b.

Discuss the ways to avoid Phishing.

A video presentation about phishing which is really nice.

Phishing Scams in Plain English

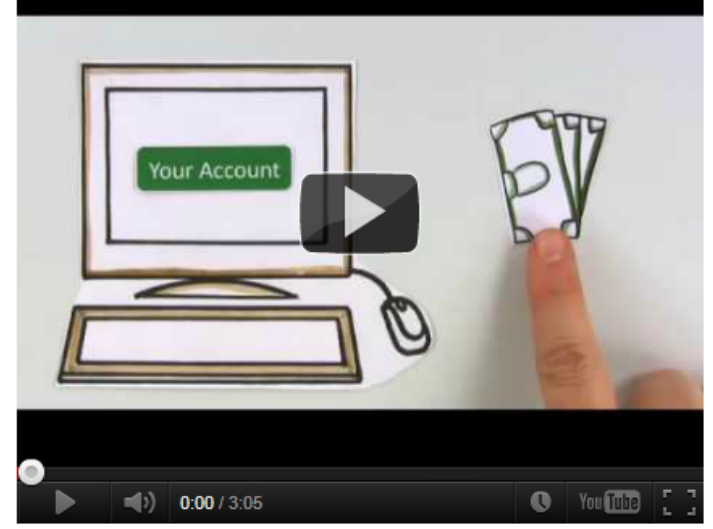

related links:

Figure 2: An example of one of the learning tasks for secondary school pupils

Group 1's topic was the "consequences of indulging in internet activities." Their wiki site contains text, videos, comics, graphics (statistical graphs), and tables. Each of the topics is presented on a sub-page. The contents include (1) a definition of internet addiction, (2) the internet addiction situation in Hong Kong, (3) the consequences of internet addiction, (4) case studies of internet addiction, (5) methods of treating internet addiction, (6) related resources, and (7) an "About Us" section which consists of assessment rubrics and reflections. An online questionnaire that assesses if a person is addicted to the Internet is also hyperlinked.

Group 2's chosen topic was "internet piracy." A variety of resources, such as text, videos, newspaper clippings, and tables, are included on their wiki site. All of the topics are presented sequentially one after another, and the group members' names and assessment rubrics are also included at the end of the wiki site even though they are not listed at the beginning of the site. The contents of Group 2's wiki site include (1) the learning objectives of the topic,; (2) the curriculum contents, which are further divided into " 2.1 What is piracy?", " 2.2 What is internet piracy?", "2.3. The effect of internet piracy on Hong Kong," "2.4 The different kinds of internet piracy," "2.5 The difficulties of protecting internet privacy," "2.6 How to protect internet privacy in Hong Kong," "2.7 Others," and "2.8 Related news"; and (3) student activities.

Group 3's topic was the "ordinances against computer crime and unauthorized access." There is no table of contents at the beginning of their wiki site, although all of the information is presented sequentially. The topics include (1) the teaching objectives of the topic; (2) the current situation; 
(3) the current statistics; (4) computer crime ordinances; (5) comparisons with other countries; (6) related materials such as related news, related documentaries, and related cases; (7) comments on computer ordinances (hyperlinked to two discussion forums); (8) student activities; and (9) assessment rubrics for the wiki site. Multimedia resources such as text, videos, and statistical tables are included on the site.

Group 4's wiki project concerns "browsers and security." A variety of multimedia resources, such as videos, screen shots, texts, and tables, are presented. The table of contents is listed at the top of the wiki site and all of the topics are presented sequentially. The topics are listed under (1) background information, which is sub-divided into "1.1. Teaching objectives"; "1.2. Teaching strategies"; "1.3. Classroom activities"; "1.4 The first teaching objective"; "1.5 The second teaching activity"; "1.6 The third teaching activity"; and "1.7 Assessment rubric for the wiki site". Group 4 did not include any resources for their assessment rubric and it is likely that the rubric they used is a consolidation of different assessment rubrics.

Group 5's topic concerns "privacy threats on the Internet". The learning objective of this topic is clearly stated at the top of the wiki site. The table of contents is listed at the top of the wiki site and all the topics are presented in separate sub-pages. Furthermore, the sub-topics appear at the end of the sub-pages for easy navigation. The topics include (1) hacking; (2) spam; (3) phishing; (4) ways to maintain privacy; (5) assessment rubric; (6) other news references; and (7) reflections. Group 5's assessment rubric was adapted verbatim from an internet source. Although the topic titles are primarily in English, some materials are in Chinese while some are in English. Even though this group of students was the first group to include videos on the wiki site, very limited multimedia resources are included in their wiki site.

The statistics of the page functions of the wiki site indicated that pages were edited over 400 times and that the participants tended to revise their project shortly after receiving feedback outside of class time. With the transparency and convenience of the wiki, the students visited the projects of the other groups and revised them at any time and any place (Lee \& Woods, 2010; Wong et al., 2006). The learning materials that were created on the wiki pages demonstrated that they had learnt through interaction with the digital materials and through inter-action among themselves (Wong et al., 2006). Therefore, wiki can provide a platform to foster student-centered learning (Research Question 1).

\section{Research Question 2}

The log functions of wiki enabled the researchers to monitor and compare the differences between the different versions of the assessment rubrics. For example, the first version of Group 3's assessment rubric was the same as the assessment rubric shown in the hyperlink (Figure 3), and they had revised it four times. Finally, they eliminated some assessment items and came up with one new item for the final version of their assessment rubric (highlighted in Figure 4). 


\section{Using Wiki to Foster Student Teachers' Learner-centered Learning and Self and Peer Assessment}

Assessment Rubric

\begin{tabular}{|c|c|c|c|c|c|}
\hline Preliminary Work & Inc. & Poo & Avg. & Good & Excellent \\
\hline Students completed storyboards prior to computer creation. & 1 & 3 & 5 & 7 & 10 \\
\hline Students included a minimum of ___ different resources. & 1 & 3 & 5 & 7 & 10 \\
\hline Students asked for permission of any copyrighted material. & 1 & 3 & 5 & 7 & 10 \\
\hline Students focused topic into workable subtopics. & 1 & 3 & 5 & 7 & 10 \\
\hline \multicolumn{6}{|l|}{ Design } \\
\hline Stack contains all presentation elements. . .introduction body, conclusion. & 1 & 3 & 5 & 7 & 10 \\
\hline Students show design elements. . .contrast between text and background, graphics, video are not obtrusive and enhance the presentation. & 1 & 3 & 5 & 7 & 10 \\
\hline Multimedia elements are visible, adequate font choices, color schemes, sizes and styles are appropriate. & 1 & 3 & 5 & 7 & 10 \\
\hline Navigation is easy and understandable. & 1 & 3 & 5 & 7 & 10 \\
\hline \multicolumn{6}{|l|}{ Content } \\
\hline Information is relevant and interesting & 1 & 3 & 5 & 7 & 10 \\
\hline Students have labeled necessary video, graphics, maps for further understanding. & 1 & 3 & 5 & 7 & 10 \\
\hline Students have used a majority of original artwork, animations, video, graphics, sounds etc. & 1 & 3 & 5 & 7 & 10 \\
\hline \multicolumn{6}{|l|}{ Presentation } \\
\hline The presentation is fluent from beginning to end. & 1 & 3 & 5 & 7 & 10 \\
\hline Students understand presentation media such as LCD panels, projectors, sound equipment, video equipment, etc. & 1 & 3 & 5 & 7 & 10 \\
\hline Students prepared and checked equipment prior to & 1 & 3 & 5 & 7 & 10 \\
\hline Overall synthesis of the presentation. & 1 & 3 & 5 & 7 & 10 \\
\hline
\end{tabular}

http://www. nosu. edu/midlinkirub. senst. htm

\section{Figure 3: First version of Group 3's assessment rubric.}

Assessment Rubric

Preliminary Work

Inc. Poor Avg. Good Excellent

Students used primary and secondary research which included factual and interesting information.

Students included different resources, such as Multi-media.

Students focused topic into workable subtopics

Design

Students showed evidence presentation synthesis

Stack contains all presentation elements. . introduction body, conclusion

Navigation is easy and understandable.

Content

Information is relevant and interesting

Students have used correct punctuation, complete sentences, grammar and spelling

Students showed complete understanding of presented material.

Presentation

The presentation is fluent from beginning to end

Overall synthesis of the presentation.

$\begin{array}{ccccc}\text { Inc. Poor } & \text { Avg. Good } & \text { Excellent } \\ 1 & 3 & 5 & 7 & 10 \\ 1 & 3 & 5 & 7 & 10 \\ 1 & 3 & 5 & 7 & 10 \\ & & & & \\ 1 & 3 & 5 & 7 & 10 \\ 1 & 3 & 5 & 7 & 10 \\ 1 & 3 & 5 & 7 & 10 \\ & & & & \\ 1 & 3 & 5 & 7 & 10 \\ 1 & 3 & 5 & 7 & 10 \\ 1 & 3 & 5 & 7 & 10 \\ & & & & \\ 1 & 3 & 5 & 7 & 10 \\ 1 & 3 & 5 & 7 & 10 \\ & & & \text { Total: }\end{array}$

http://www.ncsu.edu/midlink/rub.senst.htm

Figure 4: Final version of Group 3's assessment rubric.

Three (Groups 3, 4, and 5) of the five groups of students adapted assessment rubrics from internet sources while two groups (Groups 1 and 2) adopted assessment rubrics from internet sources without making any changes. From the wiki logs, it was deduced that the student teachers usually came up with assessment rubrics by following these steps (Research Question 2):

(1) Search for examples of assessment rubrics on the Internet.

(2) Select assessment criteria that could be used for evaluating wiki-based learning materials.

(3) Decide the number of performance levels for each criterion.

(4) Decide the rating for the chosen criteria. 


\section{Research Question 3}

None of the groups chose or developed the same assessment rubric. Four out of the five groups chose five criteria for their assessment rubrics while one group, Group 5, chose seven. However, Group 5 changed its seven assessment criteria to five after one of the course lecturers suggested that they should not simply use a selected assessment rubric. "Writing process" was changed to "readability" and "development process" and "images" were eliminated. It was logical to group "layout" and "images" together to "presentation format". Table 1 shows that "content" is the most important element in evaluating a wiki page, followed by presentation elements such as "organization" and "design" (Research Question 3). Most of the groups used a qualifier such as "excellent," "good," "satisfactory," and "needs improvement," but some used numeric scores to evaluate against the criteria.

Table 1: Summary of Criteria Adopted or Adapted in Student Teachers' Assessment Rubrics

$\begin{array}{lllll}\text { Group 1 } & \text { Group 2 } & \text { Group 3 } & \text { Group 4 } & \text { Group 5 } \\ \text { Subject Knowledge } & \begin{array}{l}\text { Content and } \\ \text { Learning of Material }\end{array} & \text { Preliminary Work } & \text { Content } & \text { Content } \\ \text { Citing Sources } & \text { Design } & \text { Design } & \text { Organization } & \text { Readability } \\ \text { Organization } & \text { Technical } & \text { Content } & \text { Attractiveness } & \text { Web Skills } \\ \text { Originality } & \text { Organization } & \text { Presentation } & \begin{array}{l}\text { Collaborative } \\ \text { Work }\end{array} & \begin{array}{l}\text { Presentation } \\ \text { format }\end{array} \\ \text { Technical } & \text { Interest } & & \text { Accuracy } & \text { Group Work }\end{array}$

\section{Research Question 4}

If descriptive scores were used in the assessment rubrics, the researchers translated the descriptors to numeric scores (i.e., "excellent" to 4, "good" to 3, "satisfactory" to 2, and "needs improvement" to 1). As for the ranking of the groups' projects, rank 1 is the best group and rank 5 is the worst group. As sometimes the rankings were the same or some groups did not rated the work of their peers, the worst group was rated 4 in most cases. The average ranking for the peers' group (Table 2) shows that Group 1 created the best learning materials, followed by groups 2, 5, 4, and 3.

Table 2 also shows that Group 5 always gave higher scores to peers' work, giving the highest marks to groups 3, 4, and 5, but other groups showed different ratings for peers' work. As three groups gave higher scores to their own work while the other groups (Groups 1 and 2) gave lower scores to their own work, there was no observable evidence that assessment rubrics can serve as viable guidelines for evaluating wiki projects through either self-assessment or peer assessment (Research Question 4). The findings confirm it is difficult to assess Web 2.0 authoring work (Anderson et al., 2007; Dron, 2006; Elliott, 2007; Nillson et al., 2005; Roberts, 2007; Sankey \& Huijser, 2009; Selwyn, 2007; The New Media Consortium \& EDUCASE Learning Initiative, 2008). 
Table 2: Summary of the Assessment Results (Rank) among the Groups

\begin{tabular}{|c|c|c|c|c|c|c|c|c|}
\hline For & $\begin{array}{c}\text { Group } \\
1\end{array}$ & $\begin{array}{c}\text { Group } \\
2\end{array}$ & $\begin{array}{c}\text { Group } \\
3\end{array}$ & $\begin{array}{c}\text { Group } \\
4\end{array}$ & $\begin{array}{c}\text { Group } \\
5\end{array}$ & $\begin{array}{l}\text { Average } \\
\text { ranking giv- } \\
\text { en to peers } \\
\text { groups }\end{array}$ & $\begin{array}{l}\text { Ranking giv- } \\
\text { en to their } \\
\text { own group }\end{array}$ & Rank order \\
\hline From & & & & & & $\begin{array}{l}\text { Peer assess- } \\
\text { ment }\end{array}$ & $\begin{array}{c}\text { Self assess- } \\
\text { ment }\end{array}$ & \\
\hline Group 1 & 4 & 1 & 1 & 3 & 2 & 1.67 & 4 & Peer $>$ Self \\
\hline Group 2 & 1 & 4 & 3 & 5 & 4 & 2.25 & 4 & Peer $>$ Self \\
\hline Group 3 & 2 & 4 & 2 & 4 & 3 & 3.25 & 2 & Self $>$ Peer \\
\hline Group 4 & 2 & 3 & 5 & 2 & Missing & 3.3 & 2 & Self $>$ Peer \\
\hline Group 5 & Missing & 1 & 4 & 1 & 1 & 3 & 1 & Self $>$ Peer \\
\hline
\end{tabular}

\section{Conclusions and Directions for Future Research}

This article has discussed an exploratory study involving the participation of student teachers intending to teach IT subject in secondary schools in Hong Kong in a wiki-based project. The userfriendly wiki platform promoted student-centered learning as all five groups of student teachers created digital learning materials and assessment rubrics in a wiki environment (Nicholas $\& \mathrm{Ng}$, 2009) on their own following the milestones and project guidelines provided by teacher-educators (Research Question 1). The findings show that the student teachers were able to search internet resources and come up with appropriate assessment rubrics (Heafner \& Friedman, 2008;

McLoughlin \& Lee, 2007) to evaluate wiki projects (Research Question 2). "Content" was the most common criterion used for assessing the wiki projects; other criteria listed by more than one group were "organization", "technical knowledge" and "design" (Research Question 3). Contrary to the common belief that assessment guides learning (Huba \& Freed, 2000, Palloff \& Pratt, 2003), the inconsistencies in the ratings for peer and self assessment using the assessment rubrics of the wiki projects' owners suggest that assessment rubrics may not be able to serve as viable guidelines for evaluating wiki projects (Research Question 4). Perhaps wiki authoring is too complex to be assessed (Anderson et al., 2007; Dron, 2006; Elliott, 2007; Nillson et al., 2005; Roberts, 2007; Sankey \& Huijser, 2009; Selwyn, 2007; The New Media Consortium \& EDUCASE Learning Initiative, 2008).

In sum, the visibility and user friendliness of wiki can foster student-centered learning and self and peer assessment among student teachers. However, due to the limited sample size, it is difficult to generalize the findings of this exploratory study. To improve this study, we could conduct a focus group meeting and analyze the reflections of the participants to complement the findings discussed in this paper. There are also two main directions for future research. First, a training session could be introduced to instruct participants how to perform an assessment prior to the actual assessment. Second, different groups could explain the assessment rubrics they created to make it easier for other groups to understand them. Last but not least, the sample size could be enlarged so that patterns might be observed. 


\section{Acknowledgement}

The authors are very thankful to all learners for participating and allowing the authors to cite their work.

\section{References}

Anderson, P. (2007). What is Web 2 .0? Ideas, technologies and implications for education JISC Technology \& Standards Watch, Feb. Retrieved from http://www.jisc.ac.uk/media/documents/techwatch/tsw0701b.pdf

Barlow, T. (2008). Web 2.0: Creating a classroom without walls. Teaching Science, 54(1), 46-48.

Barnes, C., \& Tynan, B. (2007). The adventures of Miranda in the brave new world: Learning in a Web 2.0 millennium. ALT-Journal, 15(3), 189-200.

Basque, J., Dao, K., \& Contamines, J. (2005). Participating virtually in a scientific conference: A collaborative e-learning scenario for authentic learning in higher education. Paper presented at the World Conference on Educational Multimedia, Hypermedia and Telecommunications, Chesapeake, VA.

Berlanga, A., Sloep, P., Brouns, F., Van Rosmalen, P., Bitter-Rijpkema, M., \& Koper, R. (2007). Functionality for learning networks: Lessons learned from social web applications. e-Portfolio Conference, Maastricht, Netherlands.

Berry, R. (2008). Assessment for learning. Hong Kong: Hong Kong University Press.

Biggs, J. (2001). Teaching for quality learning at university. Buckingham: Society for Research into Higher Education \& Open University Press.

Biggs, J. (2003). Teaching for quality learning at university: What the student does. Philadelphia, PA: Society for Research into Higher Education \& Open University Press.

Brown, J., \& Adler, R. (2008). Minds on fire: Open education, the long tail, and learning 2.0. EDUCAUSE Review, 43(1), 16-32.

Brown, S., \& Knight, P. (1994). Assessing learning in higher education. London: Kogan Page.

Dron, J. (2006). The pleasures and perils of social software. The Higher Education Academy Information and Computer Sciences 7th Annual Conference, Dublin, Ireland.

Education Commission. (2000). Learning for life, learning through life - Reform proposals for the education system in Hong Kong. Hong Kong: Government Printer.

Elliott, B. (2007). E-assessment: What is Web 2.0? Glasgow: Scottish Qualifications Authority.

Fry, S. A. (1990). Implementation and evaluation of peer marking in higher education. Assessment and Evaluation in Higher Education, 15, 187-189.

Godwin, P. (2007). The Web 2.0 challenge to information literacy. Inforum 2007: 13th Conference on Professional Information Resources, Prague.

Gomez, L. M., Sherin, M. G., \& Griesdorn, J. (2008). Creating social relationships: The role of technology in preservice teacher preparation. Journal of Teacher Education, 59(2), 117-131.

Gray, K., Thompson, C., Sheard, J., Clerehan, R., \& Hamilton, M. (2010). Students as Web 2.0 authors: Implications for assessment design and conduct. Australasian Journal of Educational Technology, 26(1), 105-122.

Heafner, T. L., \& Friedman, A. M. (2008). Wikis and constructivism in secondary social studies: Fostering a deeper understanding. Computers in the Schools, 35(3-4), 288-302.

Hughes, J. E. (2005). The role of teacher knowledge and learning experiences in forming technologyintegrated pedagogy. Journal of Technology and Teacher Education, 13(2), 377-402. 


\section{Using Wiki to Foster Student Teachers' Learner-centered Learning and Self and Peer}

Assessment

Huba, M. E. \& Freed, J. E. (200). Learner-centered assessment on college campuses: Shifting the focus from teaching to learning. Boston, MA: Allyn \& Bacon.

Hur, Y. (2009). An exploratory study of pre-teachers' education for educational use of moving images' UCC. Korean Journal of Teacher Education, 25(3), 199-219.

Jonassen, D. H. (2000). Computers as mindtools for schools - Engaging critical thinking. Upper Saddle River, NJ: Pearson.

Jonassen, D. H., Peck, K. L., \& Wilson, B. G. (1999). Learning with technology: A constructivist perspective. Upper Saddle River, NJ: Merrill.

Kim, H., \& Hannafin, M. J. (2009). Web-enhanced case-based activity in teacher education: A case study. Instructional Science, 37(2), 151-170.

Koehler, M., Mishra, P., \& Yahya, K. (2007). Tracing the development of teacher knowledge in a design seminar: Integrating content, pedagogy and technology. Computers \& Education, 49(3), 740-764.

Lai, Y. C., \& Ng, M. W. (2011). Using wikis to develop student teachers' learning, teaching, and assessment capabilities. Internet and Higher Education, 14, 15-26.

Lamb, K., \& McLaughlin, C. (2008). e-Assessment 07/08: Training and support initiatives. Edinburgh: JISC Regional Support Centres for Scotland.

Laurillard, D. (2002). Rethinking teaching for the knowledge society. EDUCAUSE Review, 37(1), 16-25.

Lee, S. E., \& Woods, K. J. (2010). Using contemporary topics and Internet resources to stimulate studentcentred learning. Australasian Journal of Educational Technology, 26(6), 775-790.

Lei, J. (2009). Digital natives as preservice teachers: What technology preparation is needed? Journal of Computing in Teacher Education, 25(3), 87-97.

Lim, C. P., \& Chan, B. C. (2007). Micro lessons in teacher education: Examining pre-service teachers' pedagogical beliefs. Computers and Education, 48(3), 474-494.

Mak, B., \& Coniam, D. (2008). Using wikis to enhance and develop writing skills among secondary school students in Hong Kong. System, 36, 437-455.

McLoughlin, C., \& Lee, M. J. W. (2007). Social software and participatory learning: Pedagogical choices with technology affordances in the Web 2.0 era. Proceedings of ASCILITE, Singapore.

Morris, P. (1995). The Hong Kong school curriculum: Development, issues, and policies. Hong Kong: Hong Kong University Press.

The New Media Consortium \& EDUCASE Learning Initiative. (2008). The 2008 Horizon Report. Stanford, California, USA: The New Media Consortium.

Nicholas, H., \& Ng, W. (2009). Fostering online social construction of science knowledge with primary pre-service teachers working in virtual teams. Asia-Pacific Journal of Teacher Education, 37(4), 379398.

Nillson, L., Eklof, A., \& Ottosson, T. (2005). What's so original? The discourse on education and dishonesty in the wake of a technological revolution. The 11th Biennial Conference of the European Association for Research on Learning and Instruction (EARLI), Nicosia, Cyprus.

Oldfield, K. A., \& MacAlpine, J. M. K. (1995). Peer and self-assessment at tertiary level - An experiential report. Assessment \& Evaluation in Higher Education, 20(1), 125-132.

Orsmond, P., Merry, S., \& Reiling, K. (2000). The use of student derived marking criteria in peer and selfassessment. Assessment \& Evaluation in Higher Education, 25(1), 23-38.

Paige, K., Lloyda, D., \& Chartres, M. (2008). Moving towards transdisciplinarity: An ecological sustainable focus for science and mathematics pre-service education in the primary/middle years. Asia-Pacific Journal of Teacher Education, 36(1), 19-33. 
Palloff, R. M., \& Pratt, K. (2003). The virtual student: A profile and guide to working with online learners. San Francisco: Jossey-Bass.

Pope, M., Hare, D., \& Howard, E. (2002). Technology integration: Closing the gap between what preservice teachers are taught to do and what they can do. Journal of Technology and Teacher Education, 10(2), 191-203.

Prensky, M. (2005). Listen to the natives. Educational Leadership, 63(4), 8-13.

Renner, W. (2006). E-learning 2.0: New frontier for student empowerment. Edu-Com 2006, Nong Khai, Thailand.

Roberts, E. (2007). Transforming digital content into learning. The Sixth Annual ECAR/HP Summer Symposium for Higher Education IT Executives, Boulder, Colorado.

Russell, M., Bebell, D., O'Dwyer, L., \& O'Connor, K. (2003). Examining teacher technology use: Implications for preservice and inservice teacher preparation. Journal of Teacher Education, 54(4), 297-310.

Sankey, M., \& Huijser, H. (2009). A 'likely benefit' from aligning Web 2.0 technologies with an institution's learning and teaching agenda. 2009 World Conference on E-Learning in Corporate, Vancouver, Canada.

Selwyn, N. (2007). Web 2.0 applications as alternative environments for informal learning - A critical review. Presented at the OECD-KERIS Expert Meeting - Session 6 - Alternative learning environments in practice: Using ICT to change impact and outcomes.

Vygotsky, L. S. (1978). Mind in society: The development of higher psychological processes. Cambridge, UK: Harvard University Press.

Wang, L. (2010). Implementing and promoting blended learning in higher edudcation institutions: Comparing different approaches. In E. M. W. Ng (Ed.), Comparative blended learning practices and environments (pp. 70-87). Hershey, PA: Information Science Reference.

Wheeler, S., Yeomans, P., \& Wheeler, D. (2008). The good, the bad and the wiki: Evaluating studentgenerated content for collaborative learning. British Journal of Educational Technology, 39(6), 987995.

Wong, S. L., Kamarish, A. B., \& Tang, S. H. (2006). Using a student-centred learning approach to teach a discrete information technology course: The effects on Malaysian pre-service teachers' attitude toward information technology. Technology, Pedagogy and Education, 15(2), 223-238.

Yin, R. K. (2009). Case study research: Design and methods. CA: Saga 


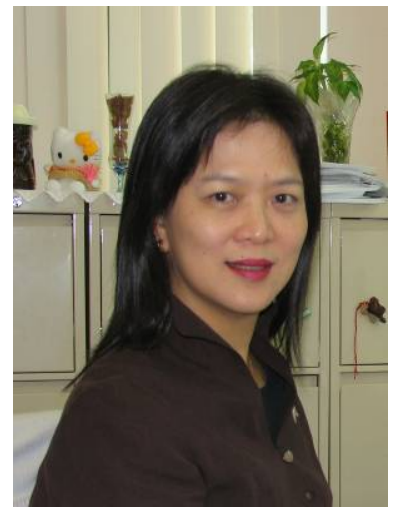

\section{Biographies}

Dr. Mee Wah Eugenia Ng is an Associate Professor (Mathematics and Information Technology Department) of the Hong Kong Institute of Education (HKIEd). She has joined the HKIEd for 16 years and has taught courses from sub-degree to doctoral level in the area of information technology in education. She has been the IT subject specialist for the Hong Kong Council for Accreditation of Academic and Vocational Qualifications since 2002. She is also very active in re-search and has been a research investigator of various internal and external funded projects. She has had over eighty articles published in conference proceedings, journals, newspapers and as book chapters in the area of IT in education or information system. She is the editor of the book entitled Comparative blended learning practices and environments and Dynamic Advancements in Teaching and Learning Based Technologies - New Concepts, editorin-Chief of International Journal of Web-based Learning and Teaching Technologies, a member of the editorial board of a number of international referred journals.

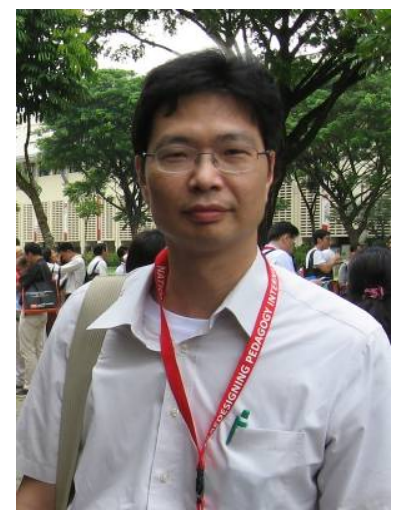

Dr. Yiu Chi Lai is an Assistant Professor of the Department of Mathematics and Information Technology at the Hong Kong Institute of Education. His current teaching and research areas include Curriculum and Teaching Methods of IT subjects, Web 2.0 in Education and Assessment for Learning. He is active in educational research and curricular resources development. He has been successful in obtaining various research grants from the General Research Fund, the Quality Education Fund and the Education Bureau. His publications include school textbooks, work-books, monographs, journal articles, conference papers, training booklets, newspaper articles, CD-ROMs, computer software, and learning websites. 